\title{
The third-worldism in the Argentinian intellectual field: a hegemonic sensibility (1961-1987) ${ }^{1}$
}

\author{
Germán Alburquerque[1]
}

\begin{abstract}
This article studies the trajectory of the Third World and third-worldism in Argentina and tries to explain how its sensibility occupied a decisive place in the Argentinian intellectual field in the 1960s and 1970s. With this purpose, the disciplines, political tendencies, and cultural movements that put the Third World between their main worries were reviewed.

Keywords: third world; third-worldism; Argentinian intellectual field.
\end{abstract}

O terceiro-mundismo no campo cultural argentino: uma sensibilidade hegemônica (1961-1987)

\section{Resumo}

Este artigo estuda a trajetória do Terceiro Mundo e do terceiro-mundismo na Argentina e tenta explicar como isso se constitui em uma sensibilidade hegemônica ao interior do campo intelectual de tal país, entre as décadas de 1960 e 1970. Com este objetivo, foram examinadas as disciplinas, as tendências políticas e os movimentos culturais que colocaram o Terceiro Mundo no centro de suas preocupações. Palavras-chave: terceiro mundo; terceiro-mundismo; campo intelectual argentino.

\section{El tercermundismo en el campo cultural argentino: una sensibilidad hegemóni- ca (1961-1987)}

\section{Resumen}

El artículo estudia el recorrido del Tercer Mundo y del tercermundismo en Argentina e intenta explicar cómo éste logró constituirse en una sensibilidad hegemónica al interior del campo intelectual de ese país entre las décadas del sesenta y setenta. Con ese fin, se revisaron las disciplinas, las tendencias políticas y los movimientos culturales que pusieron el Tercer Mundo entre sus preocupaciones centrales. Palabras clave: tercer mundo; tercermundismo; campo intelectual argentino.

\section{Le tiers-mondisme dans le domaine culturel argentin: sensibilité hégémonique (1961-1987)}

\section{Résumé}

Cet article étudie la trajectoire du tiers-monde et du tiers-mondisme en Argentine et décrit comment il est devenu une sensibilité hégémonique dans le domaine intellectuel du pays dans les années 1960 et 1970. Pour ça, on a examiné les disciplines, les tendances politiques et les mouvements culturels qui ont mis le tiers-monde au centre des préoccupations.

Mots-clés: tiers-monde; tiers-mondisme; domaine culturel argentin.

Article received on January 12, 2013, and approved for publication on March 25, 2013.

[1] Institute of Advanced Studies at Universidad de Santiago de Chile - Santiago (Región Metropolitana) - Chile. E-mail: german.alburquerque@usach.c

'This study is the result of the Proyecto del Fondo Nacional de Desarrollo Científico y Tecnológico (FONDECYT) of Post-Doctoral 3110156. 
$\mathrm{N}$ owadays, when talking about the Third World and third-worldism, outdated references come to our mind; an ideology which, by ignoring the example of developed countries and trying the opposite pathway, has defined its destiny, while engaging in a persistent and pointless criticism against capitalism. Another unreliable view of the third-worldism comes from the speech, created by rich countries, in order to keep all remaining ones under constant underdevelopment, offering them, deep down, a kind of development that is only convenient to their own interests. What is proposed here is a review of the Third World concept and the third-worldism way of thinking in its original historical dimension and in its Latin American roots.

Although this concept, having been originated in Europe in 1952, it was quickly appropriated and given a new meaning in Africa, Latin America and Asia, which acquired both claim and identity weightage, and, finally turned it into an ideology. Within our study area, Latin America, we focus on the Southern Cone and, specifically in Argentina.

How and when was the third-worldism received in Argentina? To ascertain this information is not an easy task, since there are no studies which have gone so far in this matter. Even if the study of Argentinian thought has developed itself over the years, there are yet some obscure spots to be clarified, especially considering the changes brought to light by the global thoughts at course. And so, at times marked by the so-called unique thinking, by liberalism and globalization, alternative speeches arise, putting those paradigms into check, trying to put an end to Western hegemony through a cultural return, based on local reaffirmation and respect for diversity. In this aspect, it becomes imperative to review discourses and ideologies which, in the past, had reached similar crossroads and produced solutions before the arresting of world's powers, threatening the self-determination and the autonomous culture of these men.

The third-worldism was one of these solutions, seen not only as a reaction against the Cold War and the American-Soviet growing shadow over the planet, but also against a bigger and more penetrating process, the imperialism. Hence, it is proposed to analyze this third-worldism as a way of understanding the keys to the present debate.

The history of the ideas in Argentina has taken over the role of focusing on alternative thinking. Within a series of studies that have made a long analysis of the national thinking, which had, among its best-known representatives, Óscar Terán, Carlos Altamirano, Beatriz Sarlo and Arturo Andrés Roig, the work of Hugo Biagini and of Roig himself has risen, to narrate the alternative thinking in Argentina, thus leading work crews that have not yet fulfilled their goals. ${ }^{2}$ Admittedly, the "alternative" categorization is ambiguous and questionable, first because any thinking considered to be original shall be alternative to its pre-existing one. For simplicity's sake, Roig has

${ }^{2}$ Hugo Biagini and Arturo Roig (directors), El pensamiento alternativo en la Argentina del siglo XX, 2 vols., Buenos Aires, Biblos, 2004-2006. 
demonstrated that the official thinking, which opposes the alternative one, is that of the tyrants of the politics, the greedy merchants and the dogmatic universities and churches. ${ }^{3}$

Simultaneously, throughout the recent past, it has developed what is known as the decolonization option, of which the Zulma Palermo notes are good indicators. With the tutelary collaboration of Walter Mignolo and in sync with the trends such as that of post-colonial era, the subaltern and the cultural studies, the decolonization seeks to emancipate the thinking and the science from the North-West gravitational center, which was predominant for centuries around. Before the need of reconstructing the genealogy of decolonization, Palermo turns to streams of competitive ideas in this direction:

It is the production of an alternative to the original thinking, of a different origin, which clearly sees the workings of Power, denouncing it, yet limited for belonging to the Western world in such an instable way. From there it is possible to draw a line, which goes from "national" thinking to the emerging liberation movements of the dependency theory, many of them with a projection beyond the national limits, "through cultural boundaries", with long duration effects all over Latin America. ${ }^{4}$

It is precisely in this line, between the national thinking and the dependency theory that we intend to place the third-worldism.

Going back to the initial questioning on the fertility of the Argentinian intellectual field on receiving the seed of the Third World, despite all favorable conditions, I believe such seed has germinated amidst difficulties. If compared to Brazil, we will be able to see that, in this country, the third-worldism paid off with more strength and speed, for various reasons, the first of them being the cultural, ethnic and even geographic similarity to Africa. ${ }^{5}$ As it comes to ideas, there was a similarity, due to the presence of the anti-imperialist nationalism, related to the Institudo Superior de Estudos Brasileiros (Superior Institute of Brazilian Studies - ISEB) and, more remotely, to Getúlio Vargas's populism. Moreover, in the 1950s, a group of researchers of the international relations, who were bound to diplomatic studies, had prematurely questioned the possibility of having dialogues with peripheral countries. Thus, the third-worldism has spread across various disciplines, and has assumed a prominent sensitivity, with few dissenting voices. There was also a train of thought, in Argentina, seemingly well prepared to the Third World concept, however, despite that, it could take off only during the second half of the 1960s.

\footnotetext{
${ }^{3}$ Arturo Roig, "A manera de prólogo. Hacia una acotación teórico-crítica del pensamiento alternativo como esperanza”, In: Hugo Biagini and Arturo Roig (directors), El pensamiento alternativo en la Argentina del siglo XX. Tomo Il: Obrerismo, vanguardia, justicia social (1930-1960), Buenos Aires, Biblos, 2006, p. 11-12.

${ }^{4}$ Zulma Palermo, "Introducción. Del pensamiento nacional a la opción descolonial: aportes desde el Cono Sur", In: Zulma Palermo (comp.), Pensamiento argentino y opción descolonial, Buenos Aires, Ediciones del Signo, 2010, p. 36. The underline is from the author of the article.

55ee Germán Alburquerque, "Tercer Mundo y tercermundismo en Brasil: hacia su constitución como sensibilidad hegemónica en el campo cultural brasileño - 1958-1990”, Estudos Ibero-Americanos, v. 37, n. 2 , Porto Alegre, 2011, p. 176-195.
} 
Objectively, the meaning of this work is to demonstrate that the third-worldism has installed itself in Argentina and disseminated itself widely over the intellectual field of the country, turning into hegemonic sensitivity. We understand the third-worldism in a broad sense, i.e., as an ideology, a sensitivity and a paradigm. As an ideology, it takes shape under a coherent set of ideas on both the national and international realities, which includes an explanation or diagnosis of itself and a strategy to transform it so. The third-worldism qualifies as an ideology, only if considered the flexible meaning of the word. In this sense, one must recognize that this is not a systematic and immutable set, as could be seen in the socialism, the Marxism or the liberalism, but rather than that, it consists of scattered statements gathered from different thinking lines. In terms of sensitivity, we refer to a specific attitude towards society, a positive or a negative disposition towards political, economical, cultural, religious etc. references, which translates itself into opinions, likes, preferences and interests and in decision making, integrating thus emotional and subjective elements. As a paradigm, we refer to it as a particular way of getting to know reality, based on theoretical precepts and methodological procedures. Although the third-worldism has created elements growing towards this direction, it could not quite express a strict and compact paradigm. Consequently, it would be more appropriate to consider it as a pre- or rather fragile paradigm.

\section{The third-worldism has spread across various disciplines, and has assumed a prominent sensitivity, with few dissenting voices}

In this context, we shall dedicate ourselves to the second dimension of the third-worldism, the sensitivity (which also involves ideological and of paradigm aspects), an hegemonic sensitivity, which however does not exclude the interior of the Argentinian intellectual field. If we understand, as a field, the space where circulate and relate - establishing supremacies, oppositions, complicities, neutralities etc. - the strengths (ideological tendencies, scientific paradigms, artistic and aesthetic trends), the symbolic goods (art and scientific works, speeches and manifests) and the acting people (individuals, collective or institutional), we realize the third-worldism has made itself present in all those dimensions (and in this sense, it's hegemonic), however, in tune with other sensitivities such as the liberalism, the anti-imperialism, the dependentism, the revolutionary spirits, or in more global terms, the left wing politics. In other words: in the intellectual Argentinian field of the 1960s and 1970s, the leftism sensitivity has predominated, and within that, it is possible to recognize other more limited ones, such as the third-worldism and other unmentioned ones. 


\section{The intellectual Argentinian field: the 1950s and 1960s}

Up to the middles of the century, it is possible to recognize in Argentina a tradition in political and social studies, dedicated to the prosecution of imperialism and the struggle for a genuine sovereignty. Thinkers like Raúl Scalabrini Ortiz, Arturo Jauretche, Juan José Hernández Arregui, Jorge Abelardo Ramos or Rodolfo Puiggrós were recognized, in the 1950s, as exponents of a nationalism that, in certain cases, involved Marxist analytical tools, even without dogmatism. ${ }^{6}$ Another group, relatively contemporary, has elaborated a deep reflexion over the existence and identity of the Argentinians, from a telurist posture, as the one from Ezequiel Martínez Estrada, or from a more existentialist search, as the one from Héctor Alvarez Murena or Rodolfo Kusch, promoting a determinist or essentialist essay, based in an "ontological-institutionalist" interpretation of the reality.

Even if both the groups have published content of equal or even greater importance, they soon had to share the field with the new generations of social scientists of yet more professional nature ${ }^{8}$ Economists, sociologists, and political scientists have emerged in the Argentinian intellectual field, modifying, the language - less rhetorical and more technical —, dialoguing with the foreign countries - many would study abroad — , broadening the thematic horizon and trying to intervene in the country's conduct - closer to the establishment. Let us consider, for instance, Raúl Prebisch, economist and head of the Central Bank, who rose to international prominence by an academic work outline, prior even to the founding of the Economic Commission of the Latin America and the Caribbean, or the Italian-Argentinian Gino Germani, who promoted professionalism in sociology, the knowledge from the European and North American schools and authors, the incorporation and usage of foreign scientific methods, i.e., the leap for a modernizing social science willing to change society. ${ }^{9}$

In the 1960s, a great outbreak occurred, manifesting itself in a proliferation of political-cultural magazines, with editorial fertility and the rising of several cultural centers such as the Instituto di Tella or the Instituto Desarrollo Económico y Social (Institute of Social and Economics Development - IDES). ${ }^{10}$ The phenomenon has become rooted to external and internal factors. The news from Cuba led to a conviction feeling that the revolution was indeed possible in Latin America, and in addition

\footnotetext{
"Hugo Chumbita, "Patria y revolución: la corriente nacionalista de izquierda", In: Hugo Biagini and Arturo Roig (directors), El pensamiento alternativo en la Argentina del siglo XX, vol. 2, Buenos Aires, Biblos, 2006; Oscar Terán, Historia de las ideas en la Argentina: Diez lecciones iniciales, 1810-1980, Buenos Aires, Siglo XXI, 2008. ${ }^{7}$ Oscar Terán, op cit., p. 267.

${ }^{8}$ For Terán, "this happened when disputing the space for the ontological-intuitionistic interpretation essay dominant since the 1930s. Now, the study of society should be scientific, as a neutrality condition, and it should include a evaluative analysis, away from all ideology, including in terms of politics, ori t should include a strong political and social uptake." - Terán, Historia..., op. cit., p. 277.

${ }^{9}$ Alejandro Blanco, Razón y modernidad: Gino Germani y la sociología en la Argentina, Buenos Aires, Siglo XXI, 2006. In his great work, Germani held himself to the Third World tangencially in "¿Pertenece América Latina al Tercer Mundo?", Aportes, n. 10, Buenos Aires, October of 1968.

${ }^{10}$ What takes place in universities is ambivalent. On the onde hand, they benefit from the heyday of the social sciences and the extent of registration; on the other hand, autonomy weakens before political power, which, in this case, does not let go on intervening in study sites.
} 
to that, that a profile of its own could be adopted, oblivious to the theoretical patterns. In the Cold War, USA's interest for Latin America has encouraged the sponsoring of scientific investigation and artistic creation. The international organizations - CEPAL, Facultad Latinoamericana de Ciencias Sociales (FLACSO) and Consejo Latinoamericano de Ciencias Sociales (CLACSO) - gave life to the social sciences. Internally, the political conflicts and the Peronist issue led the intellectuals into a growing ideological commitment.

Many publishers would start collections regarding
the Third World, for instance, Libros para el Tercer
Mundo; Problemas latino-americanos y del
Tercer Mundo; Biblioteca de Asia y Africa, by
Eudeba; Tercer Mundo

It is known that writers and intellectuals have taken various positions at the verge of Juan Domingo Perón's government. Many of them have backed him up the already mentioned Jauretche, Scalabrini, Hernández Arregui or Puiggrós while others, in fact most of them, kept either skeptical or repudiated him. After Perón's departure, in 1955, things started changing. The social movement has been valued, setting apart from the image of Perón, and the Peronism began to be considered a real possibility of popular emancipation. This way, the new "left wing" took shape, conceived as an overcoming of the traditional, the communist and the socialist groups, which has been organized based on basic principles, giving birth to what Sigal would call "ideological unification". ${ }^{11}$ Intellectuality in general terms - became anti-imperialist (and nationalist) and revolutionary, supporting the popular movement (intending to approach and belong to the people) and the anti-colonial struggle (a third-worldish vocational calling, let's say), and at last, in greater or lesser proportions, Marxist. ${ }^{12}$

\footnotetext{
"Silvia Sigal, Intelectuales y poder en la década del sesenta, Buenos Aires, Puntosur, 1991, p. 193. In this work, Sigal recognizes the wave of third-worldsim which has traveled Argentina in the 1960 s and that has reached a "state of horror in intelectual publications. The Argetinian progressivism had never been closed to the outside, however, before 1960, its interest was turned particularly to episodes conected to the North American domination in Latin America. Now, in turn, they are attentive to either nationalist or revolutionary moviments in countries which were, so far, nearly unknown to the Argentinians" (p. 193).

${ }^{12}$ About intelectuals and about the social sciences in Argentina in the period: Oscar Terán, Nuestros años sesentas, Buenos Aires, Puntosur, 1991; Silvia Sigal, op cit.; Beatriz Sarlo, La batalla de las ideas (1943-1973), Buenos Aires, Emecé, 2007; Bibiana G. García, Las ciencias sociales y el pensamiento crítico: ideas, prácticas e instituciones en el campo de la sociología latinoamericana de Brasil y Argentina, Documento CLACSOArgentina, 2007; José Luis de Diego, "Los intelectuales y la izquierda en la Argentina (1955-1975)", In: Carlos Altamirano (ed.), Historia de los intelectuales en América Latina II: Los avatares de la "ciudad letrada" en el siglo XX. Buenos Aires, Katz, 2010, p. 395-416; Pablo Ponza, "Comprometidos, orgánicos y expertos: intelectuales, marxismo y ciencias sociales en Argentina (1955-1973)", A Contra corriente, vol. 5, n. 2, 2008, p. 74-98; Ana María Barletta y María Laura Lenci, "Politización de las Ciencias Sociales en la Argentina. Incidencia de la revista Antropología 3er. Mundo 1868-1973”, Sociohistórica, n. 8, La Plata, 2001, p. 177-199; Anabela Ghilini, "Sociología y liberación nacional: la experiencia del grupo universitario de las 'Cátedras Nacionales"', Question, vol. 1, n. 29, La Plata, 2011, p. 1-14.
} 
On the sequence of events, the stages of the process will be reviewed in parallel and separately: at first, as the way third-worldism has been demonstrated through various dimensions; and secondly, by the way third-worldism has matured and reached its conceptual strength.

\section{Stage one: beginning and expansion of the Argentinian third- worldism (1961-1967)}

In the newly designed, politized and radical scenario, came the third-worldism, which happened a little late, in 1961. It could have been before, if the national and anti-imperialist thinkers from the 1950s had incorporated the concept, since the structure of their ideas agreed with the third-worldist approach (one could say there have been third-worldists without knowing it, or in other words, pre-third-worldists). It is the case, for instance, of Arturo Frondizi, who, back in 1955, evoked the Conference of Columbus, one of the roots of Non-Alignment (a similar, however not identical concept to the third-worldism, although some have not understood it in that sense); ${ }^{13}$ or the case of Abraham Guillén, who claimed enthusiastically the end of imperialism; ${ }^{14}$ or of Hernández Arregui, to whom "rebellion of the colonies in Asia and Africa, as well as the growing instability in Latin America, have favored the struggle for national liberation which, in turn, is part of the world politics",;5 or even of Ezequiel Martínez Estrada, who would admit a greater cultural affinity to Africa rather than Europe. ${ }^{16}$ This somewhat interesting interpretation was made by Rodolfo Puiggrós, for he would stand up for a new internationalism that "will be built from bottom to top, in the coincidence of the peoples that would break free from fetishist ideologies and oppressive systems.". ${ }^{17}$ It was not then called the Third World, however, the Mexican author, Álvaro de Faría, in his prologue calls it so. ${ }^{18}$ It was 1965 and for some reason Puiggrós ignored the concept. Did he not know it or simply he resisted to use it?

What is known for sure is that there are no explicit mentions to the Third World. Back then this expression was already well known, and even employed by the press or in international relations scenario. However, in academic and intellectual papers, this has not occurred until the historian and essayist Sergio Bagú, in a work on the Argentinian situation in the international scenario, not only has "introduced" the Third World, but also claimed his country belonged to it:

\footnotetext{
${ }^{13}$ Arturo Frondizi, La lucha antiimperialista: etapa fundamental del proceso democrático en América Latina, Buenos Aires, Debate, 1955, p. 70.

${ }^{14}$ Abraham Guillén, La agonía del imperialismo, vols. 1 y 2, Buenos Aires, Sophos, 1956-1957.

15Juan José Hernández Arregui, La formación de la conciencia nacional (1930-1960), Buenos Aires, Hachea, 1960, p. 450.

${ }^{16}$ Ezequiel Martínez Estrada, Diferencias y semejanzas entre los países de la América Latina, Caracas, Biblioteca Ayacucho, 1990 (1962)

${ }^{17 R o d o l f o ~ P u i g g r o ́ s, ~ I n t e g r a c i o ́ n ~ d e ~ A m e ́ r i c a ~ L a t i n a, ~ B u e n o s ~ A i r e s, ~ J o r g e ~ A ́ l v a r e z ~ E d i t o r, ~ 1965, ~ p . ~} 80$.

${ }^{18} / \mathrm{dem}$, Ibidem, p. 16. De Faría aboga por la integración regional como primer paso de la unión global del Tercer Mundo.
} 
Face to both kinds of economical prosperity [Soviets' and Western], the Third World - the immense gap of under-development and under-consumption to which Argentina belongs to - is in a critical period, with its economic growth indicators a little higher or way below its demographic growth ones. ${ }^{19}$

Either way, this shy first step does not put the third-worldism into current usage, though a positive predisposition is already observed.

From 1964 on, the third-worldism began to take hold and spread. In this year, the book by Logia ANAEL ${ }^{20}$ and the article by Héctor Schmucler ${ }^{21}$ were published. In the following year, the magazine La Voz del Tercer Mundo would come to the streets, and in its presentation, written by the director Diógenes Garibaldi, would express reasons as to why it was necessary to associate immediately the Third World to the Non-Alignment movement. Also, it called for counterbalancing the block's policy of safeguarding the interests of the imperialism and colonialism: "Fortunately this situation comes to an end. The peoples in development [...] joined forces to form not a new block, but a truly new world: the Third, the one from the Non-Alignment [...]".22

There are no more records of this brief publication, which even with all the publicity and being taken into foreign trade, it could signal on a policy of cultural approach, tending to strengthen market linkages. As we will see, this would be only the first of four magazines which brought the concept of the Third World along with their name.

The apex of the third-worldism would also reflect on the editorial industry. Many publishers would start collections regarding the Third World, for instance, Libros para el Tercer Mundo; Problemas latino-americanos y del Tercer Mundo; Biblioteca de Asia y Africa, by Eudeba; Tercer Mundo, by Editorial Sur. Likewise, Third World Guides were published, informing details of the peripheral countries; in this same line, there were works such as Hechos del Tercer Mundo e Hombres del Tercer Mundo, within the series Transformaciones en el Tercer Mundo, by the Centro Editor de América Latina. Everything points to the existence of a rather large public that was interested on the theme, which shows that, definitely the scene was set to the greater interference of the Third World in the Argentinian intellectual field.

\section{Stage two: splendor and maturity (1968-1974)}

The spread of third-worldism in Argentina throughout this period occurred in such a way that it reached spheres unrelated to a concept nor an ideology, but identified as international policies, developed by social scientists. These are

\footnotetext{
I9Sergio Bagú, Argentina en el mundo, Buenos Aires, FCE, 1961, p. 175.

20Logia ANAEL, La razón del Tercer Mundo, Buenos Aires, 1964.

${ }^{21}$ Héctor Schmucler, "Problemas del Tercer Mundo", Pasado y Presente, n. 4, Córdoba, 1964.

22“"Nuestra misión y su alcance", La voz del Tercer Mundo, n. 1, Buenos Aires, 1965, p. 1.
} 
the spheres which have engaged, at last, the constitution of the third-worldism in hegemonic sensitivity.

It does not come as a surprise, however, that the third-worldism would penetrate artistic expressions of high social relevance, such as the cinema, even considering Brazil's precedent, where the filmmaker Glauber Rocha had filmed and created theories on the Third World in his mind. In Argentina, something known as the Second Reunion, the Third World's Cinema Committee, organized by the Instituto del Tercer Mundo from the Universidad de Buenos Aires, in 1974, has marked the strength of a tendency which had seen its welcome results way earlier. Octavio Getino and Fernando Solanas produced the documentary La hora de los hornos (1968) inspired by a third-worldish anti-imperialist stance. In 1969, they drafted a document in which they announced the birth of a Third Cinema:

The anti-imperialist struggle of third world peoples and its kind in the midst of their own metropolises constitutes today the eye of the world revolution. The Third Cinema is, for us, the one which recognizes the greatest cultural, scientific and artistic manifestation in this fight four times, the great possibility of building, from every nation, a liberal personality: the decolonization of culture. ${ }^{23}$

The Movements of Priests to the Third World has led to another manifestation of the third-wordish sensitivity, which has spread throughout Argentina in the 1960s and 1970s. It was originated on a celebrated manifesto of bishops from the Third World - with the presence and leadership of Brazilian religious leaders, led by Helder Câmara -, which, in 1967, made a great impact in the international public opinion. Even as it had the presence of hundreds of members, it has never adopted any formal institutional framework, but as time went by, it kept defining itself, until its name made to the press. Its main concern was the Argentinian political reality, and in this context, it had issued many declarations, generally under a leftist, liberalist and Peronist perspective. It was certainly aimed at the outside world, and for the inclusion of the national evolution in the tricontinental struggle. In 1969, a document announced in Cordoba, entitled Nuestras coincidências básicas, made explicit its notions of the Third World:

An undeniable reality: the existence of countries (mainly in Asia, Africa and Latin America), and sectors within all countries, which suffer from a situation of unfairness, overwhelmed by a situation and victims to the consequences of hunger, illiteracy, lack of security, marginalization etc. A reality conveniently so-called The Third World [...] A position taking: we, Christian men and priests of the Christ, [...] feel in solidarity for this third world and servers of its needs. ${ }^{24}$

${ }^{23}$ Octavio Getino and Fernando Solanas, "Hacia un tercer cine. Apuntes y experiencias para el desarrollo de un cine de liberación en el Tercer Mundo", Hojas de cine: testimonios y documentos del nuevo cine latinoamericano, México, UAM, 1988 (1969), p. 33-34.

${ }^{24}$ In Gabriel Seisdedos, Hasta los oídos de Dios: la historia de los Sacerdotes del Tercer Mundo, Buenos Aires, San Pablo, 1999, p. 84. 
The emergence of the third-worldism in psychology was a bit bolder. Óscar Calvo developed the group dynamics, the therapeutical and educational technique, which was imported from the central countries, was accepted with enthusiasm by the Third World. However, Calvo noticed, in the classical group dynamics, one of the many weapons of imperialism's cultural domination, which would operate to neutralize critical possibilities, thus distracting the practice and moving group forces to accomplish the institutional reformism. When evoking the Brazilian Paulo Freire's liberating pedagogy, it was a bet on a conscientization dynamics which denied its former one,

assuming its limited objectives, valid ones nevertheless, and moving them with the 'what do you exist for?' that any ransacked and under-estimated Third World casts on any human group, whether the oppressor or the oppressed. ${ }^{25}$

\section{To the third-worldist social scientists, the rebellion caused by colonialism brought about the need to adequate both theory and methodology to the movement, and consequently, abandon the paradigms of Western science}

But the third-worldism would conquer a truly eccentric ground with its esoteric face. Logia ANAEL, of mysterious origins and trajectory, gets started in the third-worldism path, if we give credit to the already mentioned La razón del Tercer Mundo (1964), ${ }^{26}$ since 1956, in São Paulo. Also in this city, Doctor Anael, of an also obscure profile, gathered along with Latin American and Afro-Asiatic representatives, established the alignments focused on the elevation of the Third World. In order to accomplish that, Logia trusted Perón and the Brazilian Ademar de Barros. ${ }^{27}$ Logia and the Peronism were connected to each other by José López Rega, a man connected to Perón and to Estela Martínez who, in the 1970s, would become a minister. ${ }^{28}$ The plan was to Brazil and Argentina to turn South America into a single great federation, and thus to form, on the map, an inclined letter "L" (Lima-Buenos Aires-São Paulo), which would correspond, in turn, to a scalene triangle's vertices, the triple A (initials of America, Africa and Asia):

The first Vertex - Pequim — is allowing the peoples from the Third World to begin their liberation march. The consolidation of the second — Algeria - will speed up the march. When the three of them act side by side, the imperialist structures will begin to weaken all around. ${ }^{29}$

\footnotetext{
${ }^{25}$ Oscar Calvo, Dinámica grupal para el Tercer Mundo, Buenos Aires, Ediciones Paulinas, 1973, p. 21. ${ }^{26}$ Logia ANAEL, La razón del Tercer Mundo, Buenos Aires, 1964.

${ }^{27}$ Governor of São Paulo and candidate to Presidency.

${ }^{28}$ See Ernesto Milá, La vertiente ocultista del peronismo. La Logia Anael, Available in: <http://infokrisis.blogia. com>, Accessed on September 22 $2^{\text {nd }}, 2012$.

${ }^{29}$ Logia ANAEL, El Tercer Mundo en acción. La estructura latinoamericana, Buenos Aires, 1965, p. 8.
} 
In 1974, Logia would reinforce the spiritual aspect, guiding the actions of the analysts, for it would announce the arrival of a new socially liberated man, the Moral man. ${ }^{30}$ However, good intentions would come to an end in the Anticommunist Argentinian Alliance, the famous Triple A (already mentioned acronym), the extreme right wing paramilitary group, bound to López Rega, who spread terror all over Argentina in the 1970s. ${ }^{31}$

The third-worldism expanded its boudaries with cinema, religion, psychology and the esotericism. These expressions did not provide with a deepening of the conceptual elaboration of the Third World. We will dedicate ourselves to it later on, just mentioning here that it did develop, fundamentally, in the ideological-political level, with the contribution of militant magazines, from social sciences - which have also addressed to epistemological problems and specific political actors. The third-worldism has reached its full maturity in the heat of those discussions, producing original ideas which have, finally, constituted an ideology. ${ }^{32}$

Both the Revista de Problemas do Terceiro Mundo and the Antropología 3er Mundo have contrasted with the renowned La voz del Tercer Mundo when presenting a more efficient editorial line, also more committed and discursive. ${ }^{33}$ The first had a high quality editorial team, including well known left wing intellectuals, who have, in parts, given life to Contorno, an important publication from the 1950s. ${ }^{34}$ In the first edition editorial they would show their ideological position:

The safety in the need to contribute with the end of a system, the capitalism in its imperialist face, which has already lost all of its positive aspects for being, today, only an oppressive and destructive force, as far as it is apparently benign. ${ }^{35}$

It was considered a duty to evidence "the bonds of four national battles against the imperialist forces around the world", ${ }^{36}$ as well as to emphatically make clear that the fight against imperialism would not exclude the revolutionary option rather than socialism which was an obligatory path once the dependency relation was over: "No historical exceptionality places the societies of the Third World at the verge of the dialects of the classes". ${ }^{37}$ As we will

\footnotetext{
30 Julio César Urién, El camino del hombre: La liberación del Tercer Mundo, Buenos Aires, ANAEL, 1973, p. 402. ${ }^{31}$ We could mention other non traditional conflicts. Marcos Aguinis explored the original La cuestión judía vista desde el Tercer Mundo, Buenos Aires, Librería Superior, 1974. Also, years later though, Alcira Argumedo has referred, from a third-worldist perspective, to the technological issue and, more precisely, to communication in Los laberintos de la crisis. América Latina: poder transnacional y comunicaciones (1984), referred by Susana Barbosa, "Sobre la dependencia tecnológica: Alcira Argumedo", Juan Carlos Agulla, Ideologías politicas y ciencias sociales, Buenos Aires, Academia Nacional de Ciencias de Buenos Aires, 1996.

${ }^{32} \mathrm{About}$ the problema, the Argentinian third-worldism could be considered an ideology, and another work was dedicated, “La ideología del Tercer Mundo en Argentina. 1961-1977", Unpublished.

${ }^{33}$ Finally, the Revista Tercer Mundo has appeared in 1974, still under a more standard rather than a dissemination pattern. Only the first numbers were edited in Argentina. From 1976 on, its director, Pablo Piacentini, went into exile in México, from where he kept on producing the magazine, renamed Cuadernos del Tercer Mundo.

${ }^{34}$ The names Roberto Cossa, Ricardo Piglia, David and Ismael Viñas, Roberto Walsh, Francisco Urondo, Raúl

Sciarreta, León Rozitchner, Jorge and Andrés Rivera and Juan Carlos Portantiero are observed.

35“"Editorial”, Revista Problemas del Tercer Mundo, n. 1, Buenos Aires, 1968, p. 3.

36"Por qué Tercer Mundo", Revista Problemas del Tercer Mundo, n. 2, Buenos Aires, 1968, p. 83.

${ }^{37}$ Idem, Ibidem, p. 84.
} 
see, this statement brought about the most fervant debates concerning the Argentinian third-worldism, about the centrality of classes in relation to the nation and its people.

Mediating this polemics, the Antropología 3er Mundo was brought to life, maybe the most consistent of the magazines mentioned here, both for its persistence in time, from 1968 to 1973, and for its coherence. Work of a group of academics from the Faculty of Philosophy and Letters from the University of Buenos Aires, with an explicit leftist, Peronist guidance, the publication would defend as opposed to the classical Marxism, that the only viable internationalism was the one uniting independent peoples and fighting for freedom, not the communion of the proletarian classes of rich and poor countries, classified as meaningless abstraction. However, a third pathway was not intended between the capitalism and the socialism, and reposed its faith on a leftist way out, which would require, undoubtedly, the sum of all efforts.

The affirmation of a Third World involves both the existence of a differential Field in the international blocks game, as well as a pathway towards independency: the unification of the peoples constituting the Third World in a solitary block, fighting for national and social liberation, this is the way to get to the end of domination..$^{38}$

The social sciences have been influenced by the third-worldism, and this too was influenced by the Argentinian social sciences. It was, without a doubt, a dialectical relationship of mutual enrichment. Logically, it was the Argentinian social scientists who welcomed the Third World concept, due to its original economical and geopolitical character. Therefore, the approach was of a less "scientific" nature than the one in Brazil, where many disciplines had taken over the Third World concept, according to their particular theoretical and methodological perspectives. In Argentina, the evolution was more political and essayist, of a feeble disciplinary mediation. Those who have theorized on the Third World have struggled to develop an interpretation deriving from their political or ideological assumptions, but the concept has actually been effective beyond these areas according to sociology, economics, anthropology, history, politics or psychology professionals.

The Third World envisioned by the Argentinian social sciences, especially sociology, was a catalyst to the end of its principles. At the same time, it has allowed the elaboration of an answer to scientism, the universities' strong point. To the third-worldist social scientists, the rebellion caused by colonialism brought about the need to adequate both theory and methodology to the movement, and consequently, abandon the paradigms of Western science. Roberto Carri claimed: "we reinvigorated a singular or particular knowledge on the expression of the anti-imperialist struggle by the Third World peoples,

38“La idea de la revista Antropología 3er mundo", Antropología 3er mundo, n. 2, Buenos Aires, 1969, p. 2. 
especially the Argentinian majority" ${ }^{39}$ Gonzalo Cárdenas, however, analyzed the need to a renovation: "A new sociological stream that addresses to national and Latin American problems, and seeks its correlation to other Asian and African phenomena (contemporary social struggles) and will overcome the traditional version of sociology" ${ }^{40}$ Carlos Mastrorilli would ask straight forward for a paradigm change: "Just like Galileo and Colón have imposed a revision of science in the West, the Third World should also stir the inescapable ideological adequacy in the center". 1

It was about formulating a science in the service of liberation, which would find, in the same fight, the keys to knowledge. From the revolutionary struggle would come, in a way never seen before, the key elements. ${ }^{42}$ The Third World social science presents itself as the result of a volunteer effort rather than an authentic epistemological one. However, it is clear that the Third World was fit to be the pivot for the new concepts, which understand that the true liberation also needed its own science, breaking free from the one in the Center, qualified as an accomplice of imperialism.

\section{The revolutionary struggle is one, worldwide, being there objective conditions for solidarity for the oppressed in First, Second and Third World}

The third-worldism was not an exclusive ideology; on the contrary, it could coexist harmoniously among the others. Ever since the Third World proposed a complaint, aiming to subvert the existing order and to overcome the economical inequality, the third-worldism has become a left-wing philosophy and, as such, established a dialogue with the Communism, the Marxism, the

\footnotetext{
${ }^{39}$ Roberto Carri, "El formalismo en las ciencias sociales (2a parte)", Antropología 3er Mundo, n. 2, Buenos Aires, 1969, p. 63.

${ }^{40}$ Gonzalo Horacio Cárdenas, "La sociología neocolonialista en la Argentina", Ciencias sociales: ideología y realidad nacional, selection of Rosalía Cortés, Buenos Aires, Editorial Tiempo Contemporáneo, 1970, p. 140. ${ }^{41}$ Carlos Mastrorilli and Fernando Alvarez, Marcuse, Sartre, Nizan, Gorz y el Tercer Mundo, Buenos Aires, Carlos Pérez Editor, 1969, p. 22.

${ }^{42}$ This new paradigm was not an exclusive invention from Argentina, it has also developed in other spaces, making evident the figure of the Colombian Orlando Fals Borda, who would identify a reversion of the gernal knowledge transmission: now it would be the South teaching North the epistemological way. Following this line, the Argentinian Pedro Negre Rigol would bet in a liberation sociology: "The sociology of change in the Third World leads, at last, to the revolution theory, which involves the development and liberation [...] The revolutionary theory or theories are not formulated in the abstract [...] One shall seek its formulation in a more concrete level, with a series of analytical questions: who are the subjects of the revolution? Which are the obstacles? What conditions are there? How does the ideology transit of national liberation and of Latin America liberation, of the Third World and the world, happen?" - Sociología del Tercer Mundo, Buenos Aires, Paidós, 1975, p. 133-134.
} 
anti-imperialism, the populism, the socialism and other variants. In Argentinian territory, these dialogues also included the Peronism, the dependentism ${ }^{43}$ and the libertarianism. ${ }^{44}$

The stream to which the third-worldism was most related to was the "national socialism", a socialism associating the socialization of the means of production, the nationalization and the radical rupture with the metropolis. If to that we add the anti-imperialism - almost ubiquitous in the period's politics - and the exaltation of solidarity with the peoples of Africa and Asia, we will see that the national socialism turns into the third-worldism. According to Eduardo Astesano, "the national socialism points towards a liberating third-worldish internationalization, seeking worldwide socialization of the means of production, to overcome a national inequality and the underdevelopment." 45

As can be observed, the national socialism would in fact hide a radical internationalism. Interpreted as somewhat contradictory, it would make sense when we consider the key concepts of people, nation and class, and finally, the Marxism, which has started the whole polemic. To the third-worldism, the historical protagonism would go back to the peripheral continental peoples who would fight for their full liberation from colonialism. These peoples and nations which could be similar concepts - should join forces to ensure the end of dependency, while demanding in this way, the internationalism. The national struggle, therefore, was a priority over the classes. However, the national-socialist-third-worldism did not forget this for it was believed that, once the national liberation was consummated, the proletarian classes should lead the process.

It was confirmed that the Marxist stageism lost its validity, for the facts would evidence otherwise:

[The peoples of the Third World], with their struggles, state that there is no evolution in a unitary social whole, nor the superiority of a stage; those are the peoples which force the industrial

\footnotetext{
${ }^{43}$ The theory of dependency was well received in Argentina, and even not creating creators of much relevance, it was able to position the dependentism into an ordinary language. With the third-worldism, it had close and almost never contradictory relations, although important to point out that the dependentism had a more theoretical nature, while third-worldism would have a more direct application of its plannings with historical reality and the peripheral continents contingent.

${ }^{44}$ Libertarianism and the third-worldism hade made, in general terms, a big Exchange, and it was perfectly posible to apreciate one another. This stream gained remarkable strength in Argentina, specially with the philosophy of liberation, which was basically born in this country. The ideas of Rodolfo Kusch and Enrique Dussel reached international recognition and, in especial the last one, made relevant contributions to the colonialism debate. Both, despite having not expressly declared the Third Worlds, did not remain immune to its influence, incorporating such into their treaties. As an example, Kusch, before the "ontological saturation of the West", declared: "The solution rises [...] from culture itself, when diluting the being in fear of the cohabitation with the absolute, assuming the whole estar-siendo. However, from the estar-siendo one also deduces [...] that the access to the absolute has moved into the Third World, were there was a possibility of a salvation which would work, or as oppose to that, a solution which would save" (Esbozo de una antropología filosófica americana, Buenos Aires, Castañeda, 1978, p. 99). However, Dussel, recalling Bartolomé de Las Casas, argues that he "supposed to discover in the midst of the sixteenth century, the sin existing for five centuries in universal history: the sin of European imperial domination over their Third World colonies (Latin America, the Arabian world, black Africa, India, Southeast Asia, China). The original sin in modern world was to ignore the Indian, the African, the Asian, the "other" sacrated one, having them thurned into things, as instruments within a world of North-Atlanticdomination" (América latina: dependencia y liberación, Buenos Aires, Fernando García Cambeiro, 1973, p. 194).

${ }^{45}$ Eduardo Astesano, Nacionalismo histórico o materialismo, Buenos Aires, Pleamar, 1972, p. 206.
} 
society to "planetize" itself, without trusting in scientific need; the one who claimed the universal claiming of a capitalist stage is the result of a political planning kept alive through violence; and that, among imperial centers and dependant societies, the only logical and true relation is exclusion. ${ }^{46}$

The third-worldism, when invoking the people, has shown constance in relation to its popular version. And in this direction flows the Peronism, with which there was a historical, nearly casual binding. Juan Domingo Perón has thus created, before the emergence of the Third World, and the Non-Alignment movement, the Third Position flag, an international policy post World War II which would not consider the alignment with the USA and with the Sovietic Union, raising a strategic alternative, but yet ideological (or, more precisely, economical) alliance, which would opt for an intermediate model in relation to capitalism and socialism. Perón, already powerless, had the ability to present himself as the pioneer of third-worldism, even the Third Position lacking in some of its classical characteristics, as for example, the unity among the likeminded peripheral continents:

The Justicialism, almost twenty years ago, has established as ideological position a "third position", convinced that the way from capitalist imperialism would lead, by mistake, to the soviet imperialism. Twenty years later, it seems that the third part of the world understand it like that, which made room to the so-called "Third World", of same positioning from the Justicialism in $1945 .{ }^{47}$

The group which published Antropología 3er Mundo, also associated to the National Cátedras and to the national socialism, was explicitly Peronist, which demonstrated the communion of objectives between the Third-Worldism and the Third Position:

By placing itself as "third position" [...] the Justicialism has converted into a fully reliable doctrine to the national affirmation struggles, for, when affirming the existence of a "third position", it is affirming the irreducibility of a "Third World"; and with the assertion of this irreducibility, all the doors to contempt by such struggles close, this a traditional tactics of imperialisms. ${ }^{48}$

Recapitulating, we believe that, in this phase, the Argentinian third-worldism ends up expanding to the cultural field, constituting itself in hegemonic sensitivity, which has been proved by its presence in various disciplines, such as theology, psychology, esoterism, aesthetics etc.; by its centrality of magazines; by its influence in social sciences (the Third World is not a subject for them, but it has also altered their methods and theory); by its positioning as for political debate,

\footnotetext{
${ }^{46}$ Amelia Podetti, "Racionalidad, irracionalidad y Tercer Mundo", prologue to Norberto Wilner, Ser social y Tercer Mundo: elementos para una lógica de lo nacional, Buenos Aires, Galerna, 1969, p. 42.

47Juan Domingo Perón, La hora de los pueblos, Buenos Aires, Ediciones de la Liberación, 1973, p. 128

${ }^{48}$ Norberto Wilner, "La tercera posición justicialista y el marxismo", Antropología 3er Mundo, n. 9, Buenos Aires, 1972, p. 29.
} 
dialoguing with tendencies of great relevance alike in the Argentinian society, such as the Peronism and the national socialism. The third-worldist sensitivity has reached, at the same time, its maturity, not reducing itself to the repeatitive established phrases, for example, about the solidarity with the rest of the Third World. It goes forward with the formulation of concepts of its own, which sometimes conflicts with other systems of ideas (as, for example, the Marxism).

\section{Stage three: critics and decay (1975-1987)}

As the anti-communism grew to the extent of a strong communism, the third-worldism that emerged in Argentina reflected the success of third-worldism as it expanded. This proves that, almost every ideology would also create antibodies.

Even with the stoppage of the criticism to the third-worldism in 1975, with Juan José Sebrelli, the attacks to the doctrine would date from years before. The first manifestation of it was held by Mariano Grondona. Analytic and impartial, he, after analyzing the different postures towards the Third World came to the conclusion that Latin America could not fit into a completely third-worldist alliance, simply because its identity was different from that:

From the point of view of the "Third World", Latin America is a "conformist proletarian": subject, as the Asian nations, to the international "capital gain", however, unable to take, like them, the energy of the anti-caucasian, the anti-Christian and the anticolonial resentment. Is this not, in fact, a disconcerting position? Poor people in the material field and rich in the spiritual one, the Latin American peoples should, at once, untie the knot on this crucial dilemma. And so they will upon full access to the West, through development, merging definitely to the international proletariat. ${ }^{49}$

Less elaborated, or simply careless, were the intentions of Manuel Tagle and Carlos Sacheri, whose hostility would arise out of their religious motivations. Tagle, in a conference that took place in the symbolic Jockey Club, would attack the inventions on which the Third World would support on: the fictional underdevelopment, contradicted by the presence of Argentina itself, closer to the developed ones rather than to the poor; or the fictional ideology, since it would simulate the precedence of capitalism and communism, when in fact it was resentment for the first one and sympathy for the latter. It is here the core of his argument: the communist conspiracy against the Church, which has deceived many clergy "involved in a political adventure of communist nature covered by the malicious mask of pseudo-religiousness" ${ }^{\text {.0 }}$ Years before, Sacheri had denounced as to the third-worldism building a clandestine international church, coming from the Movement of Priests to its Argentinian correlate,

\footnotetext{
${ }^{49}$ Mariano Grondona, La Argentina en el tiempo y en el mundo, Buenos Aires, Primera Plana, 1967, p. 217. 50Manuel Tagle, ¿Qué es el Tercer Mundo?, Buenos Aires, Centro de Estudios sobre la Libertad, 1974, p. 11.
} 
the Third World. For Sacheri, it was clear that the socialism, the Marxism and the third-worldism were the same..$^{51}$

The heaviest attack came undoubtedly from the left. Juan José Sebrelli, essayist of great career, came out in defense of Marxism against the mentioned attacks of the Peronist third-worldism. He would accuse his rivals of presenting a Third World as "a world itself, as a personal entity provided with reasoning, perfectly limited and classifiable, as a determined and specific socio-economic formation". It was personified, when in fact,

it is not an objective reality, it is not a historical category, it is nothing further than an ideological figure that encompasses, as an ideology, a sublimation of reality in favor of a particular political praxis..$^{52}$

And so, he took the credit from nationalism, which would encourage poor countries and misguide the revolutionary path. For Sebrelli, in third-worldism, the 'national' would hide the 'social' when based on a lie: the interests between the native oligarchies and the proletariat. If the importance was on the national crusade for liberation, and if this crusade would be presented as a mission to unite people, the struggles among classes would alter and finally, perpetuate oppression. At last, when exalting the grouping of dependent peoples, one would get caught up in a false internationalism:

The revolutionary struggle is one, worldwide, being there objective conditions for solidarity for the oppressed in First, Second and Third World, even if they are not yet aware of this unity of interests..$^{53}$

Thus, while in third-worldism the faith in the working classes of the rich countries would be abandoned, Sebrelli would revalidate the international solidarity of classical Marxism. If, for the first ones, the new classe's struggle was the one which was encouraging peripheral peoples towards the central countries, for Sebrelli, it was yet pertinent to wait for things to calm down.

The imperialism does not substitute the class struggle by nations; on the contrary, when unifying the world by spreading the capitalist system to the last corner of the world, it universalizes the contradiction between capital and labor, taking the socialist revolution to worldwide proportions. The essential principles of Marxism, therefore, did not lose their universality. ${ }^{54}$

As a good polemist, Sebrelli would build his criticism simplifying the third-worldist speech that, in general, included sincere revolutionary ideals - and would involve the practice of not identifying opponents. His was a third-worldism which would not deny the justice of the struggle in colonized countries; he would sympathize with those and condemn imperialism, with differing strategies and fundamentals, of course.

\footnotetext{
${ }^{51}$ Carlos Sacheri, La iglesia clandestina, Buenos Aires, Ediciones del Cruzamante, 1971.

52 Juan José Sebrelli, Tercer Mundo, mito burgués, Buenos Aires, Siglo Veinte, 1975, p. 34.

53/dem, Ibidem, p. 32.

54/dem, Ibidem.
} 
In any case, the Argentinian third-worldism would begin its decline soon after Sebrelli's text. In 1976, a coup d'état would vanish with an already deteriorated democracy, making the political and academic life rather difficult. In social sciences, it was observed the decline of analyses committed to the Third World's cause and in its place would surge, more focused technical studies on the international dimension of it. The academic magazines have proliferated focused on international relations, the economy and social sciences, in general. Articles about the Third World related to the processes and successes of the time, such as the struggle to establish the New International Economic Order driven by the Non-aligned countries and the Group of the 77 - the new axis division in the North/South, the South/South cooperation, or regionally, the Argentinian Foreign Policy (discussing, for example, the rejection of the military government to the Non-alignment $)^{55}$ were published.

This activity - which has not changed with the return of democracy - would dissolve until 1987. From there, the appearings of the Third World would be very isolated, following a global trend that would strengthen with the end of the Cold War.

\section{Conclusions}

In its golden age, which we have established as being between 1968 and 1974, the third-worldism managed to build a hegemonic sensitivity in the Argentinian intellectual field. This has been demonstrated by the wide range of disciplines and ideological reception it has received due to its principles, as well as by the editorial initiatives and cultural movements that were created, based on this inspiration. It was also an incentive for the debating of ideas, which came to life in a particularly active period of the Argentinian political thinking, between the 1960s and the 1970s, adding an international perspective to it.

Having been a dominant sensitivity - as opposed to an excluding one it could focus on further development of the history of ideas. Maybe authors who have created theories on the Third World haven't been read, or mentioned. However, this apparent oblivion in which they may have fell into, does not invalidate the possibility of their preparing the grounds for further reflection on the issues related. If the de-colonial option or the alternative idea for globalization, has excelled in Argentina through these past recent years, it could have been due to that sensitivity which has managed to install itself in the reality of peripheral peoples as a whole.

\footnotetext{
55Some examples: Aldo Ferrer, "La crisis del sistema trilateral y América Latina", Estudios Internacionales, n. 42. Santiago, 1978; Cesare Augusto Carazzini, "Primero, Segundo y Tercer Mundo: hacia un nuevo orden económico mundial", Cuadernos de planeamiento, n. 2, Buenos Aires, 1977; Cesare Augusto Carazzini, "Relaciones entre el Primer y el Tercer Mundo: planes para una solución”, Cuadernos de planeamiento, n. 1, Buenos Aires, 1976; Eduardo Rabinovich, El nuevo orden económico internacional: una visión del poder en el sistema internacional, Buenos Aires, El Cid, 1984; Guillermo O’Donnell, “El aparato estatal en los países del tercer mundo y su relación con el cambio socioeconómico", Revista Internacional de Ciencias Sociales, n. 4, París, 1980; Roberto Russell y Mónica Hirst, "Democracia y política exterior: los casos de Argentina y Brasil", Estudios Internacionales, n. 80, Santiago, 1987; Roberto Russell y Teresa Carballal, "América Latina: ¿Hacia qué nuevo orden internacional?", Estudios Internacionales, n. 46, Santiago, 1979; Salvador Lozada, "Ubicarnos en el Tercer Mundo y los No Alineados", Realidad Económica, n. 52-53, Buenos Aires, 1983. Previously, but in the same direction: Carlos Pérez Llana, "América Latina y los países no alineados", Estudios Internacionales, n. 24, Santiago, 1973.
} 